\title{
Peran dan Profil Gender Rumah Tangga Tani dalam Pengambilan Keputusan Pemasaran Bunga Melati Putih (Jasmine sambac) di Kelurahan Bukit Pinang Kecamatan Samarinda Ulu Kota Samarinda
}

\author{
Firda Juita ${ }^{1}$ dan Midiansyah Effendi ${ }^{2}$ \\ 1,2 Fakultas Pertanian Universitas Mulawarman \\ 1email: : firdajuita@faperta.ac.id
}

\begin{abstract}
The purposes of this research are to know the role of wife in farm household related to decision making of marketing of jasmine white, the activity of marketing division of jasmine white flowers and the determinant factor of farm household in marketing decision of jasmine white flowers in Bukit Pinang Village, Sub District of Samarinda Ulu, Samarinda City. This research has been conducted for three months starting from May to July 2017 Sampling method used quota sampling method with the number of respondents were 30 farmers. Data analysis by using descriptive and measurement using likert scale. The results of research indicate the role of wife in farm household related to decision making of marketing of jasmine white flowers based on four indicators included in the role category with a total score of 1237 and an average of 41.23. The division of marketing activities of jasmine white flowers in farm households is mostly done by the wife. Factors that determine farm households play a role in marketing decision of jasmine white flowers is $76,67 \%$ determined by age factor and side job
\end{abstract}

Keywords: Role, Farm Household, Decision making.

\begin{abstract}
ABSTRAK
Tujuan penelitian adalah untuk mengetahui peran istri dalam rumah tangga tani terkait pengambilan keputusan pemasaran bunga melati putih, aktivitas pembagian kerja pemasaran bunga melati putih dan faktor yang menentukan rumah tangga tani dalam pengambilan keputusan pemasaran bunga melati putih di Kelurahan Bukit Pinang Kecamatan Samarinda Ulu Kota Samarinda. Penelitian ini dilaksanakan selama tiga bulan dimulai dari Mei sampai bulan Juli 2017. Metode pengambilan sampel yang digunakan metode sampel berjatah (quota sampling) dengan jumlah responden adalah 30 petani. Data analisis dengan menggunakan deskriptif dan pengukuran menggunakan skala likert. Hasil Penelitian menyatakan peran istri dalam rumah tangga tani terkait pengambilan keputusan pemasaran bunga melati putih berdasarkan empat indikator termasuk dalam kategori berperan dengan total skor 1237 dan rata-rata 41,23. Aktivitas pembagian kerja pemasaran bunga melati putih pada rumah tangga tani lebih banyak dilakukan oleh istri. Faktor yang menentukan rumah tangga tani berperan dalam pengambilan keputusan pemasaran bunga melati putih adalah $76,67 \%$ ditentukan oleh faktor umur dan pekerjaan sampingan.
\end{abstract}

Kata kunci : Peran, Rumah Tangga Tani, Pengambilan Keputusan.

\section{Pendahuluan}

Pembangunan pertanian sub sektor hortikultura di Indonesia sangat potensial untuk dikembangkan sebagai salah satu sumber perekonomian yang diharapkan dapat meningkatkan pendapatan dan kesejahteraan petani. Sejalan dengan hal tersebut, sub 
sektor hortikultura penting untuk diarahkan melalui pendekatan yang lebih sistematis, yaitu yang berwawasan agribisnis yang bermuara pada upaya peningkatan kesejahteraan bagi petani (Shinta dan Ainiyah, 2010).

Perkembangan bisnis tanaman hias yang penuh persaingan menuntut setiap pelaku usaha yang bergerak dalam usaha penjualan tanaman hias memiliki pengetahuan mengenai perilaku konsumen terhadap keputusan pembelian tanaman hias. Produsen dan pemasaran dapat menyediakan tanaman hias sesuai keinginan konsumen. Untuk itu, produsen perlu melihat perilaku konsumen dalam pembelian, karena karakteristik tanaman hias yang diinginkan konsumen tidak sepenuhnya sama dengan karateristik tanaman yang dihasilkan oleh produsen. Hal ini juga berpengaruh pada produksi tanaman hias yang dihasilkan oleh produsen. Semakin besar minat masyarakat terhadap jenis tanaman tertentu, maka permintaan akan tanaman tersebut akan naik dan memicu produsen untuk meningkatkan produksi dalam usaha taninya.

Tanaman bunga melati putih lebih dikenal sebagai tanaman hias, hampir seluruh tanaman bunga melati putih dapat dimanfaatkan, bunganya merupakan bagian tanaman yang mempunyai nilai ekonomis yang paling tinggi. Bunga melati bernilai ekonomis tinggi karena dapat diperdagangkan sebagai bunga segar. Saat ini bunga melati putih menjadi salah satu produk yang diperdagangkan di pasar dalam negeri dan luar negeri.

Kelurahan Bukit Pinang adalah kelurahan yang termasuk dalam wilayah Kecamatan Samarinda Ulu. Pada umumnya yang diusahakan adalah tanaman Hortikultura salah satunya tanaman hias yaitu bunga melati putih, luas lahan yang ditanami adalah 2 ha dengan hasil produksi sebanyak $28.800 \mathrm{~kg} /$ tahun. Bunga melati putih ini dipasarkan di wilayah Samarinda dan luar kota Samarinda khususnya Kota Bontang dan Kabupaten Berau.

Keterlibatan rumah tangga tani dalam proses budidaya melati putih sangat dibutuhkan. Tidak hanya laki-laki, perempuan juga dapat terlibat dalam menentukan pengambilan keputusan dalam hal pemasaran bunga melati putih. Tanpa keterlibatan perempuan dalam rumah tangga tani maka penilaian masyarakat terhadap partisipasi pada sektor pertanian dalam rumah tangga masih dideskriminasi. Keterlibatan wanita untuk ikut berkerja kebanyakan dilandasi oleh keinginan agar semua kebutuhan terpenuhi, baik kebutuhan keluarga maupun kebutuhan sebagai individu, yang bila mana mengharapkan semuanya dari penghasilan suami belum tentu mencukupi. Bagi kalangan yang sudah tercukupi, keinginan berkerja merupakan suatu kepuasan tersendiri.

Tujuan dari penelitian ini adalah untuk mengetahui peran istri dalam rumah tangga tani terkait pengambilan keputusan pemasaran bunga melati putih, mengetahui anggota dalam rumah tangga tani yang lebih berperan dalam aktivitas pembagian kerja pemasaran bunga melati putih dan mengetahui faktor yang menentukan rumah tangga tani berperan 
dalam pengambilan keputusan pemasaran bunga melati putih di Kelurahan Bukit Pinang Kecamatan Samarinda Ulu Kota Samarinda.

\section{Metode Penelitian}

Penelitian ini telah dilaksanakan selama tiga bulan, yang dimulai pada bulan Mei sampai dengan bulan Juli 2017. Lokasi penelitian di Kelurahan Bukit Pinang Kecamatan Samarinda Ulu Kota Samarinda.

Metode pengambilan sampel yang digunakan dalam penelitian ini adalah metode sampel berjatah (quota samping). Sampel yang diambil dari setiap kelompok tani sebanyak 10 responden yang dipilih secara sengaja (purposive), dengan ciri-ciri tertentu yaitu istri dari petani yang membudidayakan bunga melati putih lebih dari 2 tahun. Sehingga diperoleh jumlah sampel sebanyak 30 responden.

Tabel 1. Skor minimum dan maksimum dari indikator peran istri dalam rumah tangga tani terkait pengambilan keputusan pemasaran bunga melati putih di Kelurahan Bukit Pinang Kecamatan Samarinda Ulu

\begin{tabular}{clcc}
\hline No & Indikator & $\begin{array}{c}\text { Skor } \\
\text { Minimum }\end{array}$ & $\begin{array}{c}\text { Skor } \\
\text { Maksimum }\end{array}$ \\
\hline 1 & Alat Transportasi & 4 & 12 \\
2 & Penentuan Harga & 6 & 18 \\
3 & Tempat Pemasaran & 6 & 18 \\
4 & Saluran Distribusi & 3 & 9 \\
\hline & Total Skor & 19 & 57 \\
\hline
\end{tabular}

Sumber : James dan Dean, 1992

Interval kelas dalam penelitian ini tersaji pada Tabel 2 di bawah ini

Tabel 2. Interval kelas dan tingkat peran rumah tangga tani dalam pengambilan keputusan pemasaran bunga melati putih

\begin{tabular}{ccc}
\hline No & Interval Kelas & Peran rumah tangga tani \\
\hline 1. & $19,00-31,67$ & Tidak Berperan \\
2 & $31,68-44,35$ & Berperan \\
3 & $44,36-57,03$ & Sangat Berperan \\
\hline
\end{tabular}

Sumber : Suparman, 1990.

Untuk mengetahui profil gender dalam pembagian kerja dan mengetahui faktorfaktor yang menjadikan rumah tangga tani berperan dalam pengambilan keputusan pemasaran bunga melati putih dalam penelitian ini dianalisis secara deskriptif kualitatif.

\section{Hasil dan Pembahasan}

\subsection{Hasil Penelitian}

\section{Peran istri dalam rumah tangga tani terkait pengambilan keputusan pemasaran bunga melati putih}

Berdasarkan hasil observasi ditetapkan dan diukur dengan mengunakan skala Likert di dapatkan hasil peran rumah tangga tani dalam pengambilan keputusan pemasaran bunga melati putih dapat dilihat pada Tabel 3. 
Tabel 3. Peran istri dalam rumah tangga tani terkait pengambilan keputusan pemasaran bunga melati putih di Kelurahan Bukit Pinang

\begin{tabular}{llcc}
\hline No & Kategori & \multicolumn{2}{c}{ Responden } \\
\cline { 3 - 4 } & & Jumlah (jiwa) & Persentase (\%) \\
\hline 1 & Tidak Berperan & 2 & 6,66 \\
2 & Berperan & 20 & 66,67 \\
3 & Sangat Berperan & 8 & 26,66 \\
\hline \multicolumn{2}{l}{ Jumlah } & 30 & 100,00 \\
\hline
\end{tabular}

Sumber : Data primer (diolah), 2017

Peran istri dalam rumah tangga tani terkait pengambilan keputusan pemasaran bunga melati putih di Kelurahan Bukit Pinang berdasarkan skor dapat dilihat pada Tabel 4.

Tabel 4. Peran istri dalam rumah tangga tani terkait pengambilan keputusan pemasaran bunga melati putih berdasarkan empat Indikator di Kelurahan Bukit Pinang

\begin{tabular}{clcc}
\hline No & \multicolumn{1}{c}{ Indikator } & Skor & Kategori \\
\hline 1 & Alat Transportasi & 211 & Berperan \\
2 & Penentuan Harga & 459 & Sangat Berperan \\
3 & Tempat Pemasaran & 356 & Berperan \\
4 & Saluran Distribusi & 211 & Berperan \\
\hline & Jumlah & 1237 & Berperan \\
\hline
\end{tabular}

Sumber : Data primer (diolah), 2017

Berdasarkan Tabel 4 di atas, peran rumah tangga tani dalam pengambilan keputusan pemasaran bunga melati putih secara umum sangat ditentukan berdasarkan indikator sebagai berikut.

\section{a. Alat Transportasi}

Berdasarkan hasil penelitian terhadap responden dalam penentuan alat transportasi yang akan digunakan sebagai kendaraan untuk menyalurkan pemasaran hasil panen bunga melati putih di Kelurahan Bukit Pinang dapat dilihat pada Tabel 5.

Tabel 5. Peran istri dalam rumah tangga tani terkait pengambilan keputusan pemasaran bunga melati putih berdasarkan alat transportasi

\begin{tabular}{llcc}
\hline No & Kategori & $\begin{array}{c}\text { Jumlah Responden } \\
\text { (jiwa) }\end{array}$ & $\begin{array}{c}\text { Persentase } \\
(\%)\end{array}$ \\
\hline 1 & Tidak berperan & 10 & 33,33 \\
2 & Berperan & 19 & 63,33 \\
3 & Sangat berperan & 1 & 3,33 \\
\hline & Jumlah & 30 & 100,00 \\
\hline
\end{tabular}

Sumber: Data Primer (diolah), 2017

Hal ini menunjukkan peran istri dalam rumah tangga tani terkait pengambilan keputusan pemasaran bunga melati putih berdasarkan indikator alat transportasi termasuk dalam kategori berperan.

\section{b. Penentuan Harga}

Berdasarkan hasil penelitian terhadap istri petani dalam penentuan harga pemasaran hasil panen bunga melati putih dapat dilihat pada Tabel 6. Hal ini menunjukkan peran istri dalam rumah tangga tani terkait pengambilan keputusan pemasaran bunga melati putih berdasarkan indikator penentuan harga termasuk dalam kategori berperan. 
Tabel 6. Peran istri dalam rumah tangga tani terkait pengambilan keputusan pemasaran bunga melati berdasarkan penentuan harga

\begin{tabular}{llcc}
\hline No & \multicolumn{1}{c}{ Kategori } & $\begin{array}{c}\text { Jumlah Responden } \\
\text { (jiwa) }\end{array}$ & $\begin{array}{c}\text { Persentase } \\
(\%)\end{array}$ \\
\hline 1 & Tidak berperan & 10 & 33,33 \\
2 & Berperan & 1 & 3,33 \\
3 & Sangat berperan & 17 & 56,67 \\
\hline & Jumlah & 30 & 100,00 \\
\hline
\end{tabular}

Sumber : Data primer (diolah), 2017

\section{c. Tempat pemasaran}

Berdasarkan Tabel 7 menunjukkan peran rumah tangga tani dalam pengambilan keputusan pemasaran bunga melati putih berdasarkan indikator tempat pemasaran termasuk dalam kategori berperan.

Tabel 7. Peran rumah tangga tani dalam pengambilan keputusan pemasaran bunga melati putih berdasarkan tempat pemasaran

\begin{tabular}{llcc}
\hline No & \multicolumn{1}{c}{ Kategori } & $\begin{array}{c}\text { Jumlah Responden } \\
\text { (jiwa) }\end{array}$ & $\begin{array}{c}\text { Persentase } \\
(\%)\end{array}$ \\
\hline 1 & Tidak berperan & 9 & 30,00 \\
2 & Berperan & 17 & 56,67 \\
3 & Sangat berperan & 4 & 13,33 \\
\hline & Jumlah & 30 & 100,00 \\
\hline
\end{tabular}

Sumber : Data primer (diolah), 2017

\section{d. Distribusi Pemasaran}

Berdasarkan Tabel 8 menunjukkan peran istri dalam rumah tangga tani terkait pengambilan keputusan pemasaran bunga melati putih berdasarkan indikator saluran distribusi termasuk dalam kategori berperan.

Tabel 8. Peran istri dalam rumah tangga tani terkait pengambilan keputusan pemasaran bunga melati putih di Kelurahan Bukit Pinang berdasarkan distribusi pemasaran

\begin{tabular}{llcc}
\hline No & \multicolumn{1}{c}{ Kategori } & $\begin{array}{c}\text { Jumlah Responden } \\
\text { (jiwa) }\end{array}$ & $\begin{array}{c}\text { Persentase } \\
(\%)\end{array}$ \\
\hline 1 & Tidak berperan & 7 & 23,34 \\
2 & Berperan & 13 & 43,33 \\
3 & Sangat berperan & 10 & 33,33 \\
\hline & Jumlah & 30 & 100,00 \\
\hline
\end{tabular}

Sumber : Data primer (diolah), 2017

\section{Analisis Pembagian Kerja (Profil Gender)}

Analisis Deskriptif kualitatif digunakan untuk mengetahui profil gender yaitu aktivitas pembagian kerja yang melibatkan laki-laki dan perempuan dalam pengambilan keputusan pemasaran bunga melati putih dalam keluarga responden. Aktivitas tersebut terdiri dari penentuan alat transportasi, penentuan harga, penentuan tempat pemasaran dan penentuan saluran distribusi. Hasil analisis tersebut berturut-turut dibahas dalam Tabel 9 sampai 12.

\section{a. Alat transportasi}

Alat transportasi yang dimaksud dalam penelitian ini adalah alat yang digunakan oleh petani bunga melati putih dalam memasarkan hasil panen bunga melati putih. Berikut anggota keluarga petani yang berhak menentuan alat transportasi yang digunakan dalam penjualan bunga melati putih, dapat dilihat pada Tabel 9. 
Tabel 9. Pembagian kerja dalam pemasaran bunga melati putih terkait alat transportasi

\begin{tabular}{lrccc}
\hline \multirow{2}{*}{ Anggota keluarga } & Mencari Alat & $\begin{array}{c}\text { Mengendarai } \\
\text { mobil pribadi }\end{array}$ & $\begin{array}{c}\text { Melakukan } \\
\text { Pengiriman }\end{array}$ & Komplain Alat \\
\cline { 2 - 5 } & 6 & \multicolumn{4}{c}{ Jumlah Responden (jiwa) } \\
\hline Istri & 15 & 2 & 3 & 1 \\
Suami & 9 & 22 & 17 & 13 \\
Anak & 30 & 30 & 10 & 16 \\
\hline Jumlah & & & 30 & 30 \\
\hline
\end{tabular}

Sumber: Data Primer diolah, 2017

Berdasarkan Tabel 9 dapat dilihat bahwa pekerjaan yang berkaitan dengan penentuan alat transportasi lebih banyak melibatkan suami daripada istri.

\section{b. Penentuan Harga}

Pembagian kerja anggota keluarga petani yang berhak menentukan harga penjual bunga melati putih dalam rumah tangga tani, dapat dilihat pada Tabel 10 .

Tabel 10. Pembagian kerja dalam memasarkan bunga melati putih terkait penentuan harga

\begin{tabular}{lcccccc}
\hline \multirow{2}{*}{$\begin{array}{c}\text { Anggota } \\
\text { Keluarga }\end{array}$} & $\begin{array}{c}\text { Sewa } \\
\text { Alat }\end{array}$ & Upah TK & $\begin{array}{l}\text { Harga Jual } \\
\text { Konsumen }\end{array}$ & $\begin{array}{c}\text { Harga Jual } \\
\text { Perantara }\end{array}$ & $\begin{array}{c}\text { Potongan } \\
\text { Harga }\end{array}$ & $\begin{array}{c}\text { Perubahan } \\
\text { Harga }\end{array}$ \\
\cline { 2 - 8 } & & \multicolumn{7}{c}{ Jumlah responden (jiwa) } \\
Istri & 22 & 20 & 26 & 24 & 26 & 18 \\
Suami & 1 & 1 & 1 & 1 & 1 & 2 \\
Anak & 7 & 9 & 3 & 5 & 3 & 10 \\
\hline Jumlah & 30 & 30 & 30 & 30 & 30 & 30 \\
\hline
\end{tabular}

Sumber : Data primer diolah, 2017

Berdasarkan Tabel 10 dapat dilihat bahwa pekerjaan yang berkaitan dengan penentuan harga jual lebih banyak melibatkan istri daripada suami.

\section{c. Tempat Pemasaran}

Pembagian kerja anggota keluarga petani yang berhak menentukan tempat pemasaran hasil panen bunga melati putih, dapat dilihat pada Tabel 11.

Tabel 11. Pembagian kerja dalam pemasaran bunga melati putih terkait penentuan tempat pemasaran bunga melati putih

\begin{tabular}{lcccccc}
$\begin{array}{c}\text { Anggota } \\
\text { Keluarga }\end{array}$ & $\begin{array}{c}\text { Mencari } \\
\text { Pengecer } \\
\text { dalam kota }\end{array}$ & $\begin{array}{c}\text { Mencari } \\
\text { Konsumen }\end{array}$ & $\begin{array}{c}\text { Melayani } \\
\text { Konsumen } \\
\text { datang }\end{array}$ & $\begin{array}{c}\text { Mencari } \\
\text { pengecer } \\
\text { di luar kota }\end{array}$ & $\begin{array}{c}\text { Mencari } \\
\text { agen di } \\
\text { luar kota }\end{array}$ & $\begin{array}{c}\text { Konsumen } \\
\text { prioritas }\end{array}$ \\
\hline Istri & 18 & 19 & Jumlah Responden (jiwa) \\
Suami & 1 & 1 & 20 & 9 & 10 & 11 \\
Anak & 11 & 10 & 8 & 2 & 5 & 2 \\
\hline Jumlah & 30 & 30 & 30 & 19 & 15 & 17 \\
\hline
\end{tabular}

Sumber : Data Primer diolah, 2017

Berdasarkan Tabel 11 dapat dilihat bahwa pekerjaan yang berkaitan dengan penentuan tempat pemasaran bunga melati putih lebih banyak melibatkan istri daripada suami.

\section{d. Saluran Distribusi Pemasaran}

Saluran distribusi yang dimaksud dalam penelitian ini adalah saluran yang digunakan oleh petani bunga melati putih dalam menyalurkan panen bunga melati putih sampai ke konsumen. Berikut anggota keluarga petani yang berhak menentukan saluran distribusi pemasaran bunga melati putih, dapat dilihat pada Tabel 12. 
Tabel 12. Pembagian kerja dalam pemasaran bunga melati putih terkait penentuan saluran distribusi

\begin{tabular}{lccc}
\hline Anggota Keluarga & $\begin{array}{c}\text { Tanggungjawab } \\
\text { Distribusi }\end{array}$ & Mencari TK & $\begin{array}{c}\text { Menentukan Lembaga } \\
\text { Pemasaran }\end{array}$ \\
\cline { 2 - 5 } & 21 & Presentase & 15 \\
\hline Istri & 1 & 23 & 0 \\
Suami & 8 & 2 & 15 \\
Anak & 30 & 5 & 30 \\
\hline Jumlah & 2017 & 30 &
\end{tabular}

Sumber : Data primer diolah, 2017

Berdasarkan Tabel 12 dapat dilihat bahwa pekerjaan yang berkaitan dengan penentuan saluran distribusi bunga melati putih lebih banyak melibatkan istri daripada suami.

\section{Faktor-Faktor yang menentukan pengambilan keputusan dalam memasarkan bunga melati putih}

Faktor-faktor yang menentukan rumah tangga tani dalam pengambilan keputusan pemasaran bunga melati putih dapat dilihat dari beberapa indikator berikut.

\section{a. Umur Responden}

Sebaran umur responden dikelompokkan menjadi 2 kelompok berdasarkan umur produktif dan tidak produktif. Hasil pengelompokan umur responden dapat dilihat pada Tabel 13 berikut.

Tabel 13. Persentase tingkat umur rumah tangga tani di Kelurahan Bukit Pinang

\begin{tabular}{|c|c|c|c|c|c|}
\hline \multirow[t]{2}{*}{ No } & \multirow{2}{*}{$\begin{array}{c}\text { Umur } \\
\text { Responden } \\
\text { (Tahun) }\end{array}$} & \multicolumn{2}{|c|}{ Istri } & \multicolumn{2}{|c|}{ Suami } \\
\hline & & $\begin{array}{c}\text { Jumlah } \\
\text { (jiwa) }\end{array}$ & $\begin{array}{c}\text { Persentase } \\
(\%)\end{array}$ & Jumlah (jiwa) & $\begin{array}{c}\text { Persentase } \\
(\%)\end{array}$ \\
\hline 1 & $15-55$ & 24 & 80 & 21 & 70 \\
\hline 2 & $>55$ & 6 & 20 & 9 & 30 \\
\hline & Jumlah & 30 & 100 & 30 & 100 \\
\hline
\end{tabular}

Sumber: Data Primer (diolah), 2017

Berdasarkan Tabel 13, persentase umur produktif lebih banyak pada istri yaitu sebesar $80 \%$ dari 30 responden, sedangkan suami sebesar $70 \%$ dari 30 responden.

\section{b. Pendidikan Responden}

Pendidikan merupakan salah satu faktor yang dapat mempengaruhi pengambilan keputusan pemasaran bunga melati putih. Tingkat pendidikan responden dalam penelitian ini dapat dilihat pada Tabel 14 berikut.

Tabel 14. Persentase pendidikan rumah tangga tani di Kelurahan Bukit Pinang

\begin{tabular}{cccccc}
\hline \multirow{2}{*}{ No } & $\begin{array}{c}\text { Pendidikan } \\
\text { Responden } \\
(\text { Tahun) }\end{array}$ & $\begin{array}{c}\text { Jumlah } \\
\text { (jiwa) }\end{array}$ & $\begin{array}{c}\text { Persentase } \\
(\%)\end{array}$ & Jumlah (jiwa) & $\begin{array}{c}\text { Persentase } \\
(\%)\end{array}$ \\
\hline 1 & Tamat SD & 20 & 66,66 & 15 & 50 \\
2 & Tamat SMP & 5 & 16,66 & 5 & 16,67 \\
3 & Tamat SMA & 5 & 16,66 & 10 & 33,33 \\
\hline & Jumlah & 30 & 100 & 30 & 100 \\
\hline
\end{tabular}

Sumber: Data Primer (diolah), 2017

Berdasarkan Tabel 14, persentase pendidikan rendah lebih banyak dimiliki istri yaitu sebesar $66,66 \%$ dari 30 responden sedangkan suami sebesar $50 \%$ dari 30 responden. 


\section{c. Jumlah Tanggungan Keluarga}

Jumlah tanggungan keluarga merupakan jumlah orang yang tinggal dalam satu rumah, yaitu meliputi suami, istri, atau ada anggota lain dalam keluarga tersebut. Jumlah tanggungan seseorang petani juga merupakan salah satu faktor penting yang dapat mempengarui pengambilan keputusan pemasaran bunga melati putih. Berdasarkan Tabel 15, jumlah tanggungan adalah sama, yaitu $43,33 \%$.

Secara rinci jumlah tanggungan keluarga dapat dilihat pada Tabel 15 berikut.

Tabel 15. Persentase jumlah tanggungan keluarga responden di Kelurahan Bukit Pinang

\begin{tabular}{|c|c|c|c|c|c|}
\hline \multirow[t]{2}{*}{ No } & \multirow{2}{*}{$\begin{array}{l}\text { Umur } \\
\text { Responden } \\
\text { (Tahun) }\end{array}$} & \multicolumn{2}{|c|}{ Istri } & \multicolumn{2}{|c|}{ Suami } \\
\hline & & $\begin{array}{c}\text { Jumlah } \\
\text { (jiwa) }\end{array}$ & $\begin{array}{c}\text { Persentase } \\
(\%)\end{array}$ & Jumlah (jiwa) & $\begin{array}{c}\text { Persentase } \\
(\%)\end{array}$ \\
\hline 1 & $1-2$ & 13 & 43,33 & 13 & 43,33 \\
\hline 2 & $3-4$ & 13 & 43,33 & 13 & 43,33 \\
\hline 3 & $5-6$ & 4 & 13,33 & 4 & 13,33 \\
\hline & Jumlah & 30 & 100 & 30 & 100 \\
\hline
\end{tabular}

Sumber: Data Primer (diolah), 2017

\section{d. Pekerjaan Sampingan}

Pekerjaan sampingan merupakan suatu perkerjaan yang dilakukan oleh petani selain dalam usaha utamanya. Petani dalam memenuhi kebutuhan hidup rumah tangganya tidak hanya tergantung kepada pertanian atau hasil bertani, namun ada juga petani yang memiliki pekerjaan sampingan. Berdasarkan data yang diperoleh dari responden dapat dilihat pada Tabel 16.

Tabel 16. Persentase pekerjaan sampingan responden

\begin{tabular}{llcccc}
\hline No & Jenis Perkerjaan Sampingan & \multicolumn{2}{c}{ Istri } & \multicolumn{2}{c}{ Suami } \\
\cline { 3 - 6 } & & $\begin{array}{c}\text { Jumlah } \\
(\text { jiwa) }\end{array}$ & $\begin{array}{c}\text { Persentase } \\
(\%)\end{array}$ & $\begin{array}{c}\text { Jumlah } \\
\text { (jiwa) }\end{array}$ & $\begin{array}{c}\text { Persentase } \\
(\%)\end{array}$ \\
\hline 1 & $\begin{array}{l}\text { Tidak Ada Perkerjaan } \\
\text { Sampingan }\end{array}$ & 30 & 100 & 24 & 80 \\
& $\begin{array}{l}\text { Swasta } \\
\text { Jumlah }\end{array}$ & 0 & 0 & 6 & 30 \\
\hline & Jumyyyyyy
\end{tabular}

Sumber : Data Primer (diolah), 2017

Berdasarkan Tabel 23, pekerjaan sampingan tidak dimiliki oleh istri lebih besar yaitu sebesar $100 \%$, sedangkan suami sebesar $80 \%$ dari 30 responden.

\subsection{Pembahasan}

\section{Peran Istri dalam Rumah Tangga Tani terkait Pengambilan Keputusan Pemasaran Bunga Melati Putih}

Peran istri dalam rumah tangga tani terkait pengambilan keputusan pemasaran bunga melati putih Di Kelurahan Bukit Pinang termasuk kategori "berperan". Berdasarkan hasil perhitungan diperoleh skor 1.237 dengan skor rata-rata 41,23. Peran istri dalam rumah tangga tani terkait pengambilan keputusan pemasaran bunga melati putih termasuk kategori berperan pada tiga indikator, yaitu dari alat transportasi, tempat pemasaran dan saluran distribusi, sedangkan indikator penentuan harga termasuk kategori sangat berperan. Pengambilan keputusan pemasaran masih mengutamakan kesepakatan 
bersama antara suami, istri, anak maupun anggota keluarga lainnya. Usahatani bunga melati putih menjadi prioritas dalam kegiatan usaha keluarga. Seluruh anggota keluarga berperan aktif dalam menjalankan tugas dan tanggung jawabnya, baik terkait alat transportasi, penentuan harga, penentukan lokasi pemasaran dan pendistribusian bunga melati putih.

\section{Pembagian kerja (profil gender) dalam pemasaran bunga melati putih}

Pembagian kerja dalam pemasaran bunga melati putih di Kelurahan Bukit Pinang lebih banyak dilakukan oleh istri, tetapi tetap memerlukan bantuan dari suami dan anak. Pembagian kerja berdasarkan indikator dapat dilihat sebagai berikut.

\section{a. Alat transportasi}

Penentuan jenis alat transportasi harus mempertimbangkan beberapa aspek penting seperti jarak tempuh, kondisi jalan, kondisi cuaca dan banyaknya bunga melati putih yang akan dikirim. Penjualan bunga melati putih dilakukan di dalam dan luar kota, bahkan ke luar pulau Kalimantan, yaitu sampai ke Sulawesi, hal tersebut membutuhkan jenis alat transportasi berupa pesawat atau mobil minibus. Kondisi jalan menuju rumah konsumen yang berada dalam gang kecil memerlukan alat transportasi berupa motor. Jika cuaca saat pengiriman mulai mendung dan turun hujan dengan jumlah bunga melati putih yang cukup banyak yang akan dikirim, maka dibutuhkan alat transportasi yang lebih besar, yaitu berupa mobil pribadi. Pekerjaan mencari alat transportasi sewa saat tidak bisa menggunakan mobil pribadi lebih banyak dilakukan oleh suami.

\section{b. Penentuan Harga}

Harga jual bunga melati putih di Kelurahan Bukit Pinang dapat berubah sewaktuwaktu tergantung banyak sedikitnya hasil produksi, dan adanya event-event tertentu yang membuat harga jual bunga melati putih cukup tinggi, seperti saat bulan Maulid (banyaknya acara pernikahan), menjelang bulan Ramadhan, dan menjelang Hari Raya. Penentuan harga bunga melati putih ditentukan oleh rumah tangga tani itu sendiri.

Berdasarkan hasil penelitian dapat dilihat anggota keluarga yang berperan aktif dalam penentuan harga adalah istri. Penentuan harga jual didasarkan pada jenis bunga melati yang di pesan oleh konsumen, baik dalam bentuk bunga melati putih segar ataupun bunga melati yang dirangkai dengan berbagai macam ukuran yang digunakan untuk acara pernikahan, dan acara-acara sakral lainnya.

\section{c. Tempat pemasaran}

Penentuan tempat pemasaran dilakukan oleh istri. Kemampuan istri berinteraksi dengan masyarakat dengan memanfaatkan waktu saat melakukan aktivitas di luar rumah, menyebabkan istri dapat mengetahui tempat-tempat pemasaran bunga melati putih yang tepat sasaran. Istri melakukan survei langsung untuk mencari tempat pemasaran yang telah 
diinfokan, baik melalui media sosial maupun melalui komunikasi dengan masyarakat yang ditemui saat berada di luar rumah.

Pekerjaan mencari pedagang pengecer untuk wilayah Kota Samarinda dilakukan oleh istri. Beberapa pasar yang sering dikunjungi oleh istri untuk membeli kebutuhan rumah tangga sehari-hari dijadikan sebagai pengecer yang menjadi langganan tetap setiap minggunya. Pasar tradisional yang dijadikan pengecer adalah pasar yang kapasitas pengunjungmya cukup besar dan letaknya cukup strategis di wilayah Kota Samarinda, diantaranya adalah Pasar Pagi, Pasar Segiri, Pasar ljabah dan Pasar Kedondong. Bunga melati putih yang dijual melalui pedagang perantara di pasar tradisional tersebut dalam bentuk rangkaian dengan menggunakan pelepah pisang untuk kemudian di jual kepada konsumen yang ingin ziarah ke kubur atau untuk acara mandi-mandi pernikahan dan acara tujuh bulanan. Tetapi ada juga bunga melati yang dijual dalam bentuk bunga melati segar tanpa rangkaian yang dijual per kilogram $\mathrm{Rp} 100.000,00$.

Pekerjaan mencari konsumen langsung kepada pemilik salon rias pengantin dilakukan oleh istri. Istri menjalin kerjasama dengan pemilik salon rias pengantin tersebut dalam memenuhi kebutuhan asesoris pengantin ataupun acara-acara sakral lainnya, seperti wisuda, khitanan, aqiqah, mandi-mandi dan lain-lain.

Pekerjaan melayani konsumen yang datang langsung membeli ke rumah petani dilakukan oleh istri. Petani sudah mempunyai banyak pelanggan tetap setelah melakukan survei ke pasar-pasar setiap minggunya, sehingga aktivitas istri sehari-hari lebih banyak dilakukan di dalam rumah. Istri melakukan aktivitas rumah tangga dan merangkai bunga melati putih dibantu oleh beberapa orang tetangga di dalam rumah, sehingga istri dapat memberikan pelayanan langsung kepada konsumen yang datang membeli ke rumah.

Pekerjaan mencari agen dan pedagang pengecer di luar wilayah Samarinda dilakukan oleh anak. Pemesanan bunga melati putih dilakukan secara online, baik melalui website, facebook, WA ataupun BBM dengan beberapa prosedur pembelian yang ditentukan oleh pihak petani dan pengiriman dilakukan dengan menggunakan alat transportasi yang disesuikan dengan jarak pengiriman. Lokasi pengiriman di daerah Kalimantan Utara dan Pulau Sulawesi dilakukan dengan menggunakan transportasi udara melalui pesawat udara. Sedangkan untuk pengiriman wilayah Balikpapan, Bontang dan sekitarnya dilakukan dengan menggunakan transportasi darat dengan sewa minibus atau taksi.

\section{d. Saluran Distribusi}

Istri bertanggungjawab pada pendistribusian bunga melati putih sampai ke konsumen. Walaupun istri tidak terlibat langsung dalam proses pengiriman, tetapi istri mempunyai tanggung jawab penuh mulai dari pemesanan, pengemasan sampai pengiriman bunga melati putih ke konsumen. Istri bertanggung jawab mencari tenaga kerja 
tambahan jika pemesanan bunga melati putih bertambah, dengan mengambil tenaga kerja yang berasal dari keluarga terdekat ataupun tetangga terdekat yang pernah menawarkan diri untuk bekerja pada petani tersebut.

Istri bertanggung jawab mencari pedagang perantara di dalam dan di luar wilayah Kota Samarinda, walaupun untuk luar wilayah Samarinda menjadi tugas anak, tetapi tanggung jawab sepenuhnya berada di istri petani. Istri petani melakukan pencatatan penjualan yang telah dilakukan setiap hari, setiap minggu ataupun setiap bulannya. Istri mengetahui perantara yang bisa dipercaya dan yang tidak bisa dipercaya.

Menurut Hayati dan Sugiarti (2009), Khusus untuk kegiatan penanganan pasca panen, mulai dari memetik bunga, mengangkut, memasarkan, menyimpan dan merangkai bunga, hampir sebagian besar dilakukan oleh wanita. Aktivitas memanen dilakukan pada pagi hari dan setelah terkumpul, melati segera dibawa ke pasar

\section{Faktor-faktor yang menjadikan rumah tangga tani berperan dalam pengambilan keputusan pemasaran bunga melati putih}

Peran rumah tangga tani dalam pengambilan keputusan pemasaran bunga melati putih ditentukan oleh beberapa faktor, diantaranya umur, pendidikan, jumlah tanggungan dan pekerjaan sampingan.

\section{a. Faktor umur}

Umur dapat menentukan peran seseorang dalam aktivitas kerja mengelola usahatani. Wanita tani yang umurnya relatif lebih muda tentu akan mempunyai kemampuan yang lebih besar dan lebih produktif dalam mengelola usahataninya, dan sebaliknya wanita tani yang sudah memiliki usia lanjut maka ia akan cenderung untuk berpikir lebih matang dan bertindak lebih bijaksana, namun secara fisik, tenaga dan produktifitas kerjanya relatif akan menurun (Kasim dan Sirajuddin, 2008).

Rata-rata umur istri di Kelurahan Bukit Pinang yang berada di kategori produktif adalah $80 \%$, sedangakan rata-rata umur suami hanya $70 \%$ yang berada pada kategori produktif. Persentase umur produktif istri lebih besar daripada suami, hal itu menunjukkan bahwa peran istri dalam pengambilan keputusan pemasaran bunga melati putih lebih besar daripada suami. Berdasarkan hasil penelitian faktor umur menentukan rumah tangga tani berperan dalam pengambilan keputusan pemasaran bunga melati putih di kelurahan Bukit Pinang, kecamatan Samarinda Ulu kota Samarinda.

\section{b. Faktor pendidikan}

Pendidikan merupakan salah satu faktor yang dapat mempengaruhi wanita tani dalam berperan, bersikap dan mengambil keputusan. Disamping itu tingkat pendidikan dapat digunakan sebagai tolak ukur terhadap kemampuan berpikir seseorang wanita dalam menghadapi masalah dalam rumah tangga (Lestraningsih dan Basuki, 2006). 
Rata-rata pendidikan istri di Kelurahan Bukit Pinang yang berada di kategori rendah yaitu SD sebesar adalah $66,66 \%$, sedangakan rata-rata pendidikan suami hanya $50 \%$ yang berada pada kategori rendah, yaitu masih berada pada tamat SD. Persentase pendidikan istri lebih besar daripada suami, namun hal itu tidak menunjukkan bahwa peran istri dalam pengambilan keputusan pemasaran bunga melati putih lebih kecil daripada suami.

\section{c. Faktor jumlah tanggungan}

Jumlah tanggungan keluarga tani merupakan faktor yang menentukan aktivitas atau kegiatan wanita tani untuk berperan lebih dalam mengelola usahatani. Keluarga tani memiliki tanggungan keluarga yang besar, maka akan mempunyai beBan hidup yang lebih besar pula. Berdasarkan aspek jumlah tanggungan keluarga inilah yang menjadikan wanita tani harus berperan dalam mengambil keputusan dikarenakan tanggung jawab dalam rumah tangga tani (Suratiyah, 1991).

Rata-rata tanggungan rumah tangga tani di Kelurahan Bukit Pinang yang berada di kategori tanggungan 1-2 dan 3-4, yaitu sama-sama sebesar 43,33\%. Hal itu menunjukkan bahwa peran rumah tangga tani dalam pengambilan keputusan pemasaran bunga melati putih tidak ditentukan oleh banyak atau sedikitnya jumlah tanggungan. Seluruh anggota dalam rumah tangga tani bekerjasama untuk menjadikan usahtaninya lebih maju, khususnya dalam hal penanganan pasca panen bunga melati putih agar memperoleh keuntungan yang besar dari kegiatan usahataninya. Berdasarkan hasil penelitian faktor jumlah tanggungan tidak menentukan rumah tangga tani berperan atau tidak dalam pengambilan keputusan pemasaran bunga melati putih di kelurahan Bukit Pinang, kecamatan Samarinda Ulu kota Samarinda.

\section{d. Faktor pekerjaan sampingan}

Pekerjaan sampingan, merupakan faktor yang cukup berperan dalam pendapatan rumah tangga tani, walaupun aspek ini bukan merupakan aspek utama dalam tolak ukur berperannya wanita dalam pengambilan keputusan namun aspek pekerjaan sampingan ini merupakan unsur penguat sebagai penghasilan tambahan disamping penghasilan utama dari bertani, sebagai mata pencaharian pokok dalam rumah tangga tani untuk memenuhi kebutuhan hidup. Pekerjaan sampingan hanya berpengaruh terhadap pendapatan tambahan dalam keluarga tani saja, akan tetapi tidak terlalu berpengaruh terhadap peranan wanita tani dalam pengambilan keputusan. Bahwa memiliki pekerjaan sampingan akan berpengaruh pada pendapatan tambahan yang akan diperoleh dalam rumah tangga tani, sehingga pendapatan tambahan tersebut akan berpengaruh terhadap peningkatan produktivitas dalam usahatani (Ariyani, 2014).

Rata-rata pekerjaan sampingan istri di Kelurahan Bukit Pinang tidak memiliki pekerjaan sampingan sebesar $100 \%$, sedangkan rata-rata pekerjaan sampingan suami tidak mempunyai pekerjaan sampingan sebesar $80 \%$. Persentase tidak ada pekerjaan 
sampingan istri lebih besar daripada suami, hal itu menunjukkan bahwa peran istri dalam pengambilan keputusan pemasaran bunga melati putih lebih besar daripada suami. Istri yang tidak mempunyai pekerjaan sampingan akan lebih fokus dalam mengelola usahataninya, istri lebih teliti, lebih cermat, lebih kuat melakukan aktivitas, khususnya dalam hal penanganan pasca panen bunga melati putih agar memperoleh keuntungan yang besar dari kegiatan usahataninya. Berdasarkan hasil penelitian faktor pekerjaan sampingan menjadikan rumah tangga tani berperan dalam pengambilan keputusan pemasaran bunga melati putih di kelurahan Bukit Pinang, kecamatan Samarinda Ulu kota Samarinda.

Berdasarkan penelitian dari 30 responden, 23 jiwa atau 76,67\% memilih faktor umur dan pekerjaan sampingan sebagai faktor yang menentukan peran rumah tangga tani dalam pengambilan keputusan pemasaran bunga melati putih. Dan 7 jiwa atau sebesar 23,33\% memilih faktor umur, tanggungan dan pekerjaan sampingan sebagai faktor yang menentukan peran rumah tangga tani dalam pengambilan keputusan pemasaran bunga melati putih.

\section{Kesimpulan dan Saran}

Berdasarkan hasil penelitian dan pembahasan dapat disimpulkan sebagai berikut

a. Peran istri dalam rumah tangga tani terkait pengambilan keputusan pemasaran bunga melati putih berdasarkan empat indikator termasuk dalam kategori "berperan" dengan total skor 1237 dan rata-rata 41,23 dimana dalam pengambilan keputusan pemasaran bunga melati putih diambil berdasarkan kesepakatan bersama antara suami, istri, anak dan anggota keluarga lainnya.

b. Aktivitas pembagian kerja pemasaran bunga melati putih pada rumah tangga tani lebih banyak dilakukan oleh istri dalam hal penentuan harga, penentuan tempat pemasaran dan tanggungjawab pendistribusian bunga melati putih, sedangkan pekerjaan yang terkait dengan alat transportasi lebih banyak dilakukan oleh suami.

c. Faktor yang menentukan rumah tangga tani berperan dalam pengambilan keputusan pemasaran bunga melati putih adalah $76,67 \%$ ditentukan oleh kombinasi faktor umur dan pekerjaan sampingan dan $23,33 \%$ ditentukan oleh kombinasi faktor umur, tanggungan keluarga dan pekerjaan sampingan.

\section{Daftar Pustaka}

Ariyani. (2014). Peran Wanita Tani dalam pengambilan Keputusan Pemasaran Padi Sawah (Oryza sativa L.) di Desa Manunggal Jaya Kecamatan Tenggarong Seberang Kabupaten Kutai kartanegara. Skripsi. Fakultas Pertanian Universitas Mulawarman: Samarinda.

Bailon, S.G. dan A.S. Maglaya. (1998). Family Heath Nursing :The Proses Philippness : Up College on Nursing Diliman. 
BPP Sungai Kunjang. (2017). Program Penyuluhan Pertanian Kelurahan Bukit Pinang Kecamatan Samarinda Ulu Kota Samarinda.

Dalmadi. (2014). Panen dan Pasca Panen Melati. http://cybex. Pertanian.go.id/materipenyuluhan/detail/8913/panen-dan-pasca-panen. Diakses pada 23 mei 2017.

Handayani, (2015). Studi Tingkat Pengetahuan Rumah Tangga Tani Dalam Keragaman Konsumen Pangan Dusun Girirejo Kelurahan Lempake Kecamatan Samarinda Utara Kota Samarinda.

Hardiati, E dan Suwasono, S. (2006). Tataniaga Bunga Melati di Desa Labuan Tabu, Kecamatan Martakura Kabupaten Banjar. Jurnal. 6(2): 115-126.

Hayati Mardiayah dan Teti Sugiarti. Prospek Agribisnis Tanaman Melati Dan Peran Wanita Madura. Jurnal melati EMBRYO 6(1).

Heyne, K. (1987). Tumbuhan Berguna Indonesia. Jilid III. Badan Penelitian dan Pengembangan Kehutanan. Dep. Kehutanan: Jakarta, hal.1614.

Kadir,A. 2006. Transportasi: Peran dan Dampaknya dalam pertumbuhan Ekonomi Nasional. Jurnal Perencanaan dam pengembangan Wilayah WAHANA HIJAU 1(3).

Kartasasmita, G. (1996). Pembangunan Untuk Rakyat. Balai Pustaka: Jakarta

Kasim, K dan Sirajuddin, N. (2008). Peranan Usaha Wanita Peternak Itik Terhadap Pendapatan Keluarga (Studi Kasus di Kelurahan Manisa Kecamatan Baranti Kabupaten Sidrap). Fakultas Perternakan Universitas Hasanuddin: Makasar.

Lesmana, D. (2003). Peran Wanita tani Dalam Pengambilan Keputusan Penerapan Teknologi Budidaya Dan Pemasaran Salak Pondoh Ngelemut Di Kecamatan Srumbung Kabupaten Magelang. Skripsi. UGM: Yogyakarta.

Lubis, (2014). Peranan Saluran Distribusi Dalam pemasaran produk Dan jasa. Jurusan Manajemen. Universitas Sumatera Utara. Fakultas Ekonomi: Medan.

Mahastanti. L dan Nugrahanti Y.(2010). Peranan Wanita Pendamping Suami Menjalankan Bisnis Keluarga dalam Pengembangan Bisnis Studi Industri Kecil Kerupuk Di Tuntang Kabupaten Semarang. Jurnal Siasat Bisnis 14(1):43-53.

Sajogyo, P. 2013. Peran Wanita dalam Perkembangan Ekonomi. Obor. Jakarta.

Shinta dan Ainiyah. (2010). Analisis Kelayakan Finalsial Usahatai melati (Jasminum sambac L) dan Usahatani Sedap Malam (Polianthers tuberase L) Jurusan Sosial Ekonomi Pertanian, Universitas Brawijaya: Malang.

Widyarini. (2013). Peran Wanita Tani Dalam Pengembangan Usaha Tani Sayuran Organik Dan Peningkatan Pendapatan Keluarga di Desa Melung Kecamatan KedungBanteng.Jurusan Sosial Ekonomi Pertanian Fakultas Pertanian Unsoed. Jurnal Ilmu pemerintahan,3,(1) 2015:433-442.

William F, Juch, Lawrence R, Glueck. (1995). Manajemen Strategis dan Kebijakan Pemasaran. Erlangga: Jakarta.

Yani, D. E. (2012). Pola Pengambilan Keputusan Wanita Tani Pada Usahatani Sayuran Sentra Sayuran Daratan Tinggi di Kecamatan Tangelangan. Jurnal Mtk, Sains, Dan Teknologi 13(2). 